\title{
URBAN PILGRIMS TOURISM - LOCAL COMMUNITY AND VISITORS PERSPECTIVE (ST. STANISLAUS KOSTKA SANCTUARY IN WARSAW)
}

\author{
ANNA PAWLIKOWSKA PIECHOTKA, ${ }^{1}$ ANNA OSTROWSKA-TRYZNO, ${ }^{2}$ \\ KAROLINA GOŁĘBIESKA ${ }^{3}$
}

\author{
Faculty of Tourism \& Recreation WTIR AWF Warsaw \\ ${ }^{1}$ e-mail: anna.piechotka@gmail.com \\ 2 e-mail: anna.tryzno@gmail.com \\ 3 e-mail: karolina.golembieska@gmail.com
}

\section{JEL CODES \\ KEYWORDS}

ABSTRACT
$\mathrm{Z} 32$

urban tourism, sacred sites, pilgrims, sustainable spatial planning, local community

Today we can observe an increasing popularity of short-term pilgrimage visits, religious excursions to the urban sacred centres. On the example of St. Stanislaus Kostka Church in Warsaw, we intended to study the impact that tourism is having on the nearby housing estate and local community (Żoliborz Borough, Warsaw).

The basic issue of our study (conducted in the Faculty of Tourism and Recreation, AWF University Warsaw: 2014-2016) was to seek the answer for the following questions: the number of visitors, how much income they inject into the local economy, the number of jobs created, the impact of tourism on the image of the city, the local community's approach to tourists as "strangers", and also the visitor comments on amenities and infrastructure. To examine urban tourism from the local community perspective and to obtain primary data, we have undertaken the explanatory research (based on observation and social survey work as a basis to explain a phenomenon) and evaluative research (policy of St. Stanislaus Kostka Church and local authorities decision-making grounds associated with the pilgrimage tourism process. We also used statistic information (as secondary data).

Social-science perspectives and spatial studies showed that shared space (tourists, local community) creates some conflicts, such as problems with parking space, overcrowded local shops, and much higher prices than in shops located in the nearby districts. On the other hand, local community is clearly proud of such an important holy site. It would seem that more attention should be paid to the negative consequences of visitor's presence and that it is necessary to identify in future local plans more carefully several issues connected with tourist presence. 


\section{Introduction}

Tourism is now one of major areas of academic concern, recognised as significant because of the enormous impact it has on the local community lives and on places in which they live (Hall, 2000; Korstanje, 2011). Most of tourism studies have been restricted to economic analysis and benefits occurring to the area (Inskeep, 1991; Law, 2001). However recently, concern has been aired on the existence of negative impacts, especially resented by local community (Archer, 2005; Kowalczyk 2010; Kurek 2013; Selby, 2004; Timothy, 2003). Although it seems that the religious tourism impact could be only positive, as responding to spiritual needs, connected with sacred motivations and having several thousand years' worth of history - care must be taken to monitor the scale and nature of development, before destinations become irrevocably damaged (Smith, 2003). Religious tourism, as other tourism segments, must be connected with issues of sustainable development (Kapera, 2011; Kazimierczak 2012; Kowalski, 2011; Panasiuk, 2011, Mikos von Rohrsheidt, 2011; Rotherham, 2009; Swatos, 2002). This paper offers insight into very special tourist attraction, which is urban sanctuary. Warsaw has always attracted visitors, but in the recent years tourism has significantly increased, one of the popular form is short-term pilgrimage visit to the holy sites. On the example of St. Stanislaus Kostka Church in Warsaw, we intended to study the impact of tourism on nearby housing estate and local community. Challenges and considerations in the planning and development of pilgrim tourism are then summarized (based on case study). Propositions are presented for guiding collaborative initiatives in the local planning and development of tourism, from a community-involvement perspective.

\section{Research methods}

The basic issue of our study was to seek the answer for the following questions: the number of visitors per year in the sanctuary, how much income they inject into the local economy, the number of jobs created, the impact of tourism on the image of the city, the local community approach to tourists as "strangers", and also the visitor comments on amenities and infrastructure. As individual's ability to tolerate the behaviour of other people, the social context of local residents are all important determinants, thus evaluating the tourist and local resident experience is a complex process. Therefore, the different research methods and tools associated were used: qualitative approach together with quantitative approach (Finn, 2000; Law, 2002; Phillimore 2004; Selby, 2004; Timothy, 2003). To examine urban tourism from the local community perspective and to obtain primary data, we have undertaken the explanatory research (based on observation and social survey work as a basis to explain some phenomenon) and evaluative research (policy of the sanctuary administration and the local authorities decision-making grounds associated with the pilgrimage tourism). We also used statistic information (as secondary data). This paper describes the results of interviews conducted face to face, in situ during the spring and summer of 2016 (MarchSeptember) in an attempt to examine empirically the existence of these impacts of tourism. A total of 50 pilgrims visiting the sanctuary, 50 permanent residents living in the up to 300 meters distance from the church and 14 entrepreneurs (owners of: hair-dress salon, bicycle workshop, restaurants 
(2 sites), bookshop, coffee shops (3 sites), bistro, drugstore, groceries (2 sites), architects design studio and kindergarten) located nearby the sanctuary were interviewed. We used both structured and semi-structured questionnaires. The collected material was analysed to measure the character of tourism, motivation to travel and perception of how tourism impacts on different local community domains. A comparison analysis was also made between our respondents' attitudes toward tourism and their dependence on tourism for a livelihood. ${ }^{1}$

\section{Case study results}

Religious tourism comprises many segments of the travel industry including: pilgrimages, missionary travels, monastery visits, faith-based camps and religious tourism attractions. Pilgrimage is understood as a journey to a sacred place of great importance and search of spiritual feelings of great moral signifies (Loykie, 2007). Many ancient religions had holy sites, temples and groves, where pilgrimages were made (Karnak and Thebes in Egypt; Delphi and Epirus in Greece, Ephesus in Turkey; Baalbek in Lebanon or Jerusalem in Israel). Today members of many major religions participate in pilgrimages. Moreover, in modern usage, the terms pilgrim and pilgrimage have developed in sense to include sites of secular importance. For example, fans of Elvis Presley visit his home Graceland in Memphis (US), popular are visits to war memorials such as the Vietnam Veterans Memorial and famous cemeteries such as Pere Lachaise Cemetery in Paris - which are often seen as pilgrimages. Although a pilgrimage is normally viewed in the context of religion, the personality cults cultivated by communist and fascist leaders ironically gave birth to pilgrimages of their own. In the totalitarian system (communism, fascism) secular pilgrimages were established intended as an "antidote" to religious pilgrimages, the most famous of which are: Lenin's Mausoleum in Red Square, Moscow, Mausoleum of Mao Zedong in Beijing. This type of pilgrimage to a personality cult is still evident today on people who pay visits of homage to both secular and sacred sites.

In Warsaw, there are 9 sanctuaries formally recognised by the Roman Catholic Church, and an example of a sacred site connected with both sacred and secular importance is St. Stanislaus Kostka Church, Rev. Jerzy Popiełuszko Tomb and Memorial Centre. Rev. Jerzy Popiełuszko (1947-1984) was a charismatic priest associated strongly with the Solidarity Union movement. In his famous sermons, he interwove spiritual and political messages, criticizing the Communist system and motivating people to protest. The Stużba Bezpieczeństwa (SB - internal intelligence agency) tried to silence or intimidate him and in consequence in 1984 he was murdered. More than 250,000 people, including the Nobel Prize Winner Lech Wałęsa, attended his funeral. Rev. Jerzy Popiełuszko has been recognized as a martyr and was beatified in 2010 in the presence of more than 100,000 people attending the open-air mass. Rev. Jerzy Popiełuszko was one of the most vocal priests involved in the Solidarity movement and today St. Stanislaus Kostka Church in Warsaw has become

\footnotetext{
${ }^{1}$ These structured interviews were conducted face to face, in situ by the students of the Faculty of Tourism and Recreation AWF University Warsaw, performed as their assignment in 2016 (under supervision of Prof. Anna Pawlikowska-Piechotka).
} 
a gathering point for those who wanted to pay a tribune not only to his memory, but also to thousands of other Solidarity Union members, victims of the past regime. Today in the neighbourhood of the St Stanislaus Kostka Church live about 5,000 people, around 10\% of Żoliborz Borough inhabitants. This area, enclosed between streets: Slowackiego, Mickiewicza, Stołeczna (re-named as 'Rev. Popielszko Street') and Aleja Wojska Polskiego, forms the central part of Żoliborz Borough. With approximately 50,000 inhabitants, it is one of the smallest boroughs of Warsaw. Wartime destruction was not so severe in Żoliborz district and despite the consequences of infamous 'Bierut Decree' (1945), cancelling private properties, most of the 'old' local community members remain in their apartments. This explains a very special atmosphere of the area, inhabited by people respecting tradition and history, paying high respect to the local identity. The Żoliborz Borough, founded in 1930s is recognised as one of the high points in the European architecture. The wide streets, open areas, numerous pocket gardens, public parks and squares built there are regarded as fine examples of responsible and rational urban planning, interesting architecture, serving as a manifesto of the Polish Modernism. Several star-shaped squares were built along the main axis of the borough, with the Plac Wilsona (Wilson's Square) as the traditional borough's centre and main transport hub (with the underground station 'Plac Wilsona'). Today around the Plac Wilsona there are several restaurants, cafes, banks and shops serving both the local community and pilgrims visiting the holy site.

As we have found during our survey, the determinants of pilgrim travels to the Żoliborz Borough were not built on purely religious ground and we managed to identify a range of other motivations. Despite devotional and spiritual purposes there are also other:

- shopping (mainly in the nearby "Arkadia Shopping Centre"),

- a desire to travel, to escape from a known environment, to experience some new stimuli,

- very cheap excursion opportunity (most of pilgrims are low-income rural farmers, retired elders, school groups or unemployed),

- family and social interactions (very popular are school or parish community pilgrim groups),

- patriotism (Rev. Jerzy Popiełuszko Memorial Centre is connected with the Solidarity Union history),

- cultural and education purposes: pilgrim travel program often encompasses some visits to other sanctuaries and museums in Warsaw, sightseeing the Old Town, theatre performance or concert.

Focusing on the residents of Żoliborz Borough, this research examined the differences in tourism perception and attitudes toward pilgrims across the local community. The survey results indicated mixed feelings and both positive and negative impacts were recognised. As it was emphasised, at first the strong support for Solidarity Union created the positive attitude, in favourability with increasing tourism development. Nevertheless, a few years ago a threshold level of pilgrimage development was achieved, beyond which attitudes become less favourable. The results showed that residents support for special tourist fees and taxes increases with increasing levels of tourism development. This research examined also relationships between tourism attitudes, length 
of residency, level of tourism development, and feelings of community attachment in the Żoliborz Borough. A significant relationship was found between the duration of residency and attachment: people living there only for last ten years used to complain more about masses of tourists (overcrowded shops, road traffic problems), however those living at Żoliborz Borough more than ten years were more understanding, saying the pilgrims has been part of history and tradition of this area. Clearly, they expressed much more attachment and emotional sense of place, a readiness to share the history and tradition of place (they are very proud of) with others. Moreover some 'old' local community members (about 30\%) saw benefits (better public transport, caring for infrastructure, great selection of retails, banks and restaurants). Nevertheless, the others (about 60\%) felt there were too many tourists and claimed that from their perspectives, the disadvantages of tourism outweighed the advantages. One of them angrily confessed: 'On religious festivals I have to take my bus very early in the morning to avoid the traffic disruptions caused by the numerous tourist coaches'. The other said that in his opinion, masses of pilgrims create not only safety hazards but also reduce the special atmosphere of a sacred site. About $10 \%$ of local residents claimed that they could not identify any major impact of pilgrims on the area (in terms of socio-cultural consequences). All shops and restaurants owners (14 responses) were satisfied with the present level of pilgrimage, hoping for development and looking forward to increasing their business and income in future.

\section{Conclusion and discussion}

1. If tourism is to be sustainable, it must create positive opportunities for community development, protect the environment, improve security and health care, offering a better future. In many instances tourism can be seen as a vehicle to empower local communities through the development of new employment opportunities, the enhancement of local economies, and preservation of history, public awareness and education. To develop tourism in a sustainable manner it is necessary to define optimal tourism development limits to secure minimum impact or disruption for the environment and local communities. As many scholars and international law agreements (EU, UNESCO) underline, when sustainability values are in question, alternatives to mass pilgrim tourism should be considered to ensure that tourism can benefit both tourists and local communities (Archer, 2005; Dredge, 1992; Drost, 1996; Harrison, 2005; Kowalczyk 2010, 2013; Kurek 2012, Newman, 2011; Page, 2003; UNESCO ICOMOS, 2011; Vael, 2002).

2. In order for pilgrim tourism to become a sustainable at Żoliborz Borough, local authority and individuals must work together to shape new concepts. Ideally, participatory spatial planning and implementation will be a part of the processes. To ensure community involvement and to safeguard local cultures, planning process should involve all stakeholders in tourism development at all appropriate levels, facilitate the development of tourism services that are planned, managed and reviewed by the host community, ensure that tourism revenue stays in the host community to enhance livelihoods and generate a profitable source of income, empower and motivate local groups to direct cross-cultural exchange in the way they wish and adopt practices which conserve, protect and preserve the environment. To make these possible the financing assistance should: 
- provide funds for applied research through pilot projects to determine optimal mechanisms for tourism development in a range of differing circumstances;

- create small-scale credit lines to assist small enterprises to invest in pilgrim tourism without excessive risk on personal property

3. There is an urgency to constructively shape tourism in order to support local development and conservation goals. According to the Spatial Act Law, this must be planned within the framework provided by the Local Plans Strategy and its declarations. All the stakeholders involved in and affected by pilgrim tourism should be involved in the development of action plans for sustainable pilgrim tourism in Żoliborz Borough. Identifying mechanisms to achieve sustainable development goals in tourism must be a priority for co-operation. 'Good practices' (such as zoning regulations) in conserving culture and history of the site while developing sustainable tourism should involve all stakeholders. Different associations and institutions, not only local government, but also societies and NGOs should co-operate to launch a dialogue process on sustainable pilgrim tourism:

- ensure that tourism development is in line with the priorities and land-use plans and that the public can participate in local and regional decision making,

- regulate tourism to ensure that profits benefit local people and conservation efforts,

- develop and support programmes to revitalise the diverse aspects of local cultures (modernistic architecture of Żoliborz Borough),

- promote consultation processes in tourism planning, involving local communities,

- develop participatory programmes to support the integrity of local culture and history of Żoliborz Borough,

- analyse the experience with sustainable pilgrim tourism in different European cities to disseminate methodology/positive examples of community involvement in tourism,

- consider 'Zoning Regulations', which could demarcate specific areas for different types of land users (local residents, pilgrims) - to secure sustainable space sharing,

- consider wider cooperation with local NGOs and schools.

As presented outcomes of our research results show, at present masses of pilgrims in the small community of Żoliborz Borough quite often (especially during religious events) creates anxiety and discord among local residents. In the case of this quiet, cameral district, which attracts some 50,000 pilgrims a year, our survey showed clearly that there is an ambivalent 'love-hate' relationship with tourism. However, Żoliborz Borough community, as it seems, can also gain from the infrastructure that comes to their area as a result of pilgrim tourism (as better public transport, more retails and banks, possibility to develop own enterprise - as the small or medium - scale 'family business').

In our opinion, discussion should now be focused on what could be done to alleviate the present negative physical and socio-cultural input of mass tourism and to make a real change in everyday life of local community. It seems that zoning regulations could demarcate specific areas for different types of land use (residential area, sacred area, parking sites) and detailed standards should be applied within each zone to ensure the standards are followed. Hopefully much more engaged local community involvement in the plan and decision-making strategy for spatial development of 
Żoliborz Borough may create a sense of co-ownership of the sacred site within the community and residents, may feel different about local heritage as guardians and protectors of tradition and history they are proud of and ready to share with others. It is a believe that pilgrim tourism in Żoliborz Borough could also contribute to cultural, educative development and a hope that spatial conflicts could be solved that creates the setting for tourism planning (Pawlikowska-Piechotka, 2009). In our opinion a deeper understanding of the socio-cultural impact of tourism on local community can be achieved only by a much greater engagement of the local authority, planning works conducted within the interdisciplinary teams (including specialist in sociology, theology, geography, architecture and urban planning, infrastructure engineers), undertaken with the St Stanislaus Kostka Church representatives and the tourism planning practitioners.

\section{Acknowledgment}

The presented research outcomes were based on the research study material conducted in the Faculty of Tourism and Recreation AWF University Warsaw, on the base of the Ministry of Science and Higher Education grant ds-245 AWF (2014-2016).

\section{Refrences}

Archer, B., Cooper, Ch., Ruhanem, L. (2005). The Positive and Negative Impacts of Tourism. Global Tourism (Theobald William F. edit.). 75-103; Elsevier New York.

Dallen, J.T., Stephen, W.B. (2003). Heritage Tourism. Harlow Essex: Prentice Hall.

Dredge, D., Moore, S. (1992). A methodology for the integration of tourism in town planning, Journal of Tourism Studies, $3(3-1), 8-27$.

Drost, A. (1996). Developing sustainable tourism for world heritage sites. Annals of Tourism Research, 2 (23), $479-484$. DOI: $10.1016 / 0160-7383(96) 83345-7$.

European Commission. Regional Policy (2011). Cities of tomorrow. Challenges, visions, ways forward, EC. Retrieved from: http://www.europa.eu (29.02.2016).

Finn, M.; Elliott-White, M.; Walton, M. (2000). Tourism and Leisure Research Methods. Pearson London.

Hall, M.C. (2000). Tourism Planning. Harlow Essex: Prentice Hall.

Harrison, D., Hitchcock, M. (2005). The politics of world heritage. Negotiating tourism and conservation. Paris: UNESCO World Heritage Centre.

Inskeep, E. (1991). Tourism planning: an integrated and sustainable development approach. New York: Van Nostrand Reinhold.

Kapera, I. (2011). Samorząd terytorialny a rozwój turystyki religijnej i pielgrzymkowej w Krakowie. Zeszyty Naukowe Uniwersytetu Szczecińskiego, Turystyka religijna - zagadnienia interdyscyplinarne, 647, 271-282.

Kazimierczak, M. (2012). Duchowy wymiar podróżowania. Folia Turistica, 27, 5-21.

Korstanje, M.E. (2011). Influence of history in the encounter of guests and hosts. Anatolia, 2 (22), 282-285.

Kowalczyk, A.(2013). Turystyka kulturowa. Warszawa: Wydawnictwo Naukowe PWN.

Kowalczyk, A. (2010). Turystyka zrównoważona. Warszawa: Wydawnictwo Naukowe PWN.

Kowalski, T., Ruszkowski, M. (2011). Miejsca kultu religijnego jako czynnik atrakcyjności regionu, Zeszyty Naukowe Uniwersytetu Szczecińskiego, 647, 71-84.

Kurek W. (2012). Turystyka. Warszawa: Wydawnictwo Naukowe PWN. 
Lovelock, B., Lovelock, K.M. (2013). The Ethics of Tourism. Critical and Applied Perspectives. New York: Routledge. Law, M.Ch. (2002): Urban Tourism. London: Continuum.

Lomine, L., Edmunds, J. (2007). Key Concepts in Tourism. New York: Palgrave.

Newman, P., Thornley, A. (2011). Planning World Cities. Globalisation and Urban Politics. New York: Palgrave-Macmillan. Page, S.J.; Hall, C.M. (2003). Managing Urban Tourism. Harlow: Prentice Hall.

Panasiuk, A. (2011). Dylematy promocji produktu turystyki religijnej. Zeszyty Naukowe Uniwersytetu Szczecińskiego, $647,361-373$.

Pawlikowska-Piechotka, A. (2009). Zagospodarowanie turystyczne i rekreacyjne. Gdynia: Novae Res.

Pawlikowska-Piechotka, A. (2013). Planowanie przestrzeni turystycznej. Gdynia: Novae Res.

Phillimore, J., Goodson, L. (2004). Qualitative Research in Tourism. New York: Routledge.

Mikos von Rohrsheidt, A.(2011). Faktyczna dostępność obiektów sakralnych, jako problem turystyki religijnej w Polsce. Zeszyty Naukowe Uniwersytetu Szczecińskiego 647, 35-58.

Rotherham, I. (2009). Sustaining Tourism Infrastructure for Religious Tourists and Pilgrims within the UK. Religious Tourism and Pilgrimage Festivals Management (pp. 64-77). London: CABI Publishing.

Rinchede, G. (2002). Forms of religious tourism. Annals of Tourism Research, 1 (19), 51-67.

Selby, M. (2004). Understanding Urban Tourism. London: I.B. TAURIS.

Smith, M.K. (2003). Issues in Cultural Tourism Studies. New York: Routledge.

Swatos, W.H., Tomasi, L. (2002). From Medieval pilgrimage to religious tourism. Chicago: Praeger Publishers.

Timothy, D.J., Boyd, S.W. (2003). Heritage Tourism. Harlow: Prentice Hall.

UNESCO ICOMOS (2011). The Valetta Principles for the Safeguarding and Management of Historic Cities, Towns and Urban Areas. Paris: UNESCO.

Vael, A.J. (2002). Leisure and Tourism. Policy and Planning. London-New York: Routledge. DOI: 10.1079/97808519 95465.0000 . 


\section{TURYSTYKA PIELGRZYMKOWA W WIELKIM MIEŚCIE A SPOŁECZNOŚĆ LOKALNA - SANKTUARIUM ŚW. STANISŁAWA KOSTKI W WARSZAWIE}

\section{SŁOWA KLUCZOWE}

STRESZCZENIE turystyka miejska, sanktuaria, pielgrzymi, planowanie zrównoważone, społeczność lokalna

Obecnie możemy obserwować nie słabnącą popularność krótkich pielgrzymek, których destynacją są miejskie sanktuaria religijne. Na przykładzie kościoła św. Stanisława Kostki w Warszawie, usiłowaliśmy rozeznać wpływ, jaki ma ruch turystyczny na mieszkańców pobliskich domów, a szerzej - społeczność lokalną Dzielnicy Żoliborz. Podstawowym celem naszej pracy badawczej, zrealizowanej na Wydziale Turystyki i Rekreacji AWF w Warszawie w latach 2014-2016, było poszukiwanie odpowiedzi na następujące pytania: wielkości ruchu pielgrzymkowego, wpływu jaki ma na rozwój lokalnej przedsiębiorczości, na kreowanie miejsc pracy, na tożsamość miejsca, na wizerunek dzielnicy; jaki jest stosunek społeczności lokalnej do pielgrzymów oraz komentarze pielgrzymów odnośnie przygotowania sanktuarium pod kątem ich odwiedzin (w tym ułatwienia dla osób starszych i niepełnosprawnych). Szukając odpowiedzi na postawione pytania, posłużyliśmy się metodą badań empirycznych: przede wszystkim badań terenowych, wizji lokalnych, obserwacji uczestniczącej jawnej, strukturalizowanymi wywiadami przeprowadzonymi in situ face to face wśród pielgrzymów i przedstawicieli społeczności lokalnej. Uzyskany w ten sposób materiał o charakterze jakościowym został uzupełniony danymi statystycznymi uzyskanymi od administracji sanktuarium i Urzędu Dzielnicy. Badacze przedmiotu zwracają uwagę na możliwy konflikt pojawiający się w sytuacji 'przestrzeni dzielonej', użytkowanej dla różnych, nierzadko sprzecznych ze sobą, funkcji. Taki problem okazał się wyrazisty w przypadku badanego sanktuarium i jego otoczenia; społeczność lokalna narzeka na tłumy pielgrzymów i turystów, ceny w lokalnych sklepach - znacznie wyższe niż w sąsiednich częściach tej samej dzielnicy, zatłoczone wąskie uliczki i nieustające problemy z parkowaniem. Z drugiej strony przedstawiciele społeczności lokalnej nie ukrywali dumy z powodu słynnego sanktuarium w ich sąsiedztwie. Aby łagodzić negatywne konsekwencje ruchu turystycznego dla mieszkańców okolic żoliborskiego sanktuarium, konieczne jest pilne przygotowanie strategii zrównoważonego rozwoju turystyki z uwzględnieniem szerokich konsultacji społecznych i uważnego wysłuchania głosów zarówno społeczności lokalnej, organizatorów ruchu pielgrzymkowego jak i zarządzających sanktuarium. 